COMMENT

Received 3 May 2016 | Accepted 7 Jun 2016 | Published 5 Jul 2016

\title{
Digging for perfection: discourse of deformity in Richard III's excavation
}

Marcela Kostihova ${ }^{1}$

ABSTRACT Shakespeare's Richard III, the archetypal world-infamous villain, has long served as an informative case study for the tendency of humanity to categorize the nonnormative and surprising as repulsive. This article considers the ways in which the public spectacle of excavation of Richard III's skeleton in Leicester harnessed Shakespeare's cultural capital to address contemporary anxieties with non-normative bodies. This article is published as part of a collection to commemorate the 400th anniversary of William Shakespeare's death. 
S hakespeare's Richard III, the archetypal world-infamous villain, has long served as an informative case study for the tendency of humanity to categorize the non-normative and surprising as repulsive. As William Ian Miller persuasively argues, our culture has tended to find deformity disturbing because it "doesn't fit" with our concept of the rightness of the world (Miller, 1997: 45). The normative visual aesthetic, he continues, constitutes "a moral standard which, if breached can evoke horror, disgust, pity, and fear" (82). While deformity encountered in everyday life frequently provokes anxiety, in presenting a dilemma of looking/ not looking, seeing/ignoring, Shakespeare's public display of Richard's body invites a gleeful contemplation of the nonnormative, and harnesses the resulting horror/disgust/fear as tools of the larger tragedy. Widely on display, Richard had thus come to function as a symbol of warped humanity, sending scholars to lengthy deliberations about the manifest interconnection between non-normative embodiment and inherent evil-he has the distinction of having been maligned as the "arch-defective in all literature" and the prime example of "malevolent disability" (Snyder, 2005: 272).

What has fascinated me-and I've waxed lengthily about this elsewhere ${ }^{1}$-is the ambivalence and permeability of this embodiment. Perhaps because the character's actions are so ghastly, and because we remain wedded to the ideological perceptions that evil be written on the body, we frequently forget that we have few clues (when reading the play) of what is actually wrong with him, if anything. While negative epithets demonstrating his enemies' negative views of his character and personality abound (a "poisonous bunch-backed toad", 4.4.81, is my personal favourite), it's interesting that not a single character in the play provides evidence of a physical deformity or deficiency. The clues we have come from Richard himself, and his record is inconsistent-he refers to various maladies at times when they would serve him well and raise pity in the auditors, but none seem to measure up in parallel action (his lament that his disability precludes him from being a "lover", for instance, is spectacularly belied by his serial successful wooing of women who should know better than to be seduced by him). If anything, Richard is an unreliable narrator whose words should be taken with some salthis exact embodiment, then, is notoriously open to discussion.

Perhaps one of the reasons why it's easy to forget the ambiguity of Richard's embodiment in the play is that we inevitably function within the discourse of its stage history. While the textual contours of his non-normativity are mercurial, the fact of his disability seems unshakable, as production after production has inscribed a disability (usually a hunched back and a withered arm, but others abound) onto the body of the character, visualizing (and this was my earlier argument) the ideological delineation of normativity (in both conceptualization of disability and ethical behaviour) in the cultural context of each production. In other words, Richard's disability differs from production to production based on the normative boundaries of the receiving culture, both physical and temporal. We tend to find Shakespeare's Richard deeply disturbing, in body and soul, but the focus of that disturbance proves to be contextual and grounded, with unfailing and surgical precision, in our anxieties about the non-normative "threatening" forces of the disenfranchised in our midst-those with non-normative bodies, behaviours and needs.

I was in the midst of writing about the ways in which several productions of Shakespeare's Richard III demonstrate this trend when the media came alive with new information, released on 2 December 2014, about the "real" Richard, so recently dug upand subsequently scrutinized with unprecedented global intensity - under a "car park" in Leicester. These reports, too, crawled with references not only to Shakespeare, but also to the uneasy conflation between the remains of his body and the evidence that such remains could possibly reveal about his interiority-his intentions, his likes and dislikes, and his overall psychology. Despite the fact that (at least some of) the scientists valiantly maintained that even the most sophisticated DNA analysis of his wisdom teeth "can't tell us anything about Richard the man" (Morris, quoted in Burns, 3), the overall discourse inevitably slid into a gleeful voyeuristic reconsideration of whether Shakespeare was "right" in his assessment of Richard as a villain, firmly embedded within the body that was found, a body that proved to have a "severe idiopathic scoliosis" of 60-80 degrees.

Instead of mapping the ways in which we tend to use Shakespeare capital in theatrical productions to explore our own anxieties about non-normative bodies, I turn to examining the ways in which the theatre of discovery of the unfolding ULAS (University of Leicester Archaeological Services) excavation and subsequent skeletal analysis followed the same template. I attempt a preliminary analysis of the public discourse surrounding the excavation of a likely Grey Friars site in Leicester that unexpectedly and serendipitously yielded the barely disturbed remains of one of the most vilified characters in history and literature, the last English king to die in battle, whose remains were long thought to have floated away in River Soar. The whole process has become shrouded in an aura of miraculous authenticity-the long lost king was found, science identified him beyond all reasonable doubt, and, thanks to modern analysis, as Mantel (2013) opined in a controversial piece in the London Review of Books, "the king ... has been reclothed in his true identity" (8/14). My preliminary thesis is that, despite decades of research and activism, the discourse generated by the scientific reports of the dig, the media heyday that surrounded it, and the cultural icons that weighed in (not to mention the popular responses archived in comment sections of all online articles and numerous social media sites, which I will not bring to bear on this preliminary analysis), our culture insists on coherence between personal appearance and moral interiority, and, even more troublingly, conflates non-normative embodiment (or disability) with evil interiority. The excavation of Richard III demonstrates a widespread desire for authenticity and the erasure of ambiguity, and for science-endorsed coherence between embodiment and morality.

Despite jokes that the true identification of the skeleton comes from the "telling absence of any trace of a horse" in its vicinity (quoted in Pitts, 2014: 143), the bulk of the conversation about Richard III's identity evolves-perhaps inevitably-around a careful scrutiny of his embodiment, wherein his pronounced disfigurement disability, his "funny back" (Pitts, 2014: 154), is the most prominent and discussed trait. Commissioned by the Richard III society, the excavation was to prove, once and for all, that Richard was not what Shakespeare (and other detractors) had made him to be. Per central Website of the international Richard III society (2015), the society has "been working since 1924 to secure a more balanced assessment of the king and to support research into his life and times", always looking for "new opportunities to make the case for 'Good King Richard' ". Before the actual finding of Richard's remains, the society unequivocally denied any non-normativity associated with the king. They maintained that he had been a good and considerate ruler, "a goodly king, harsh in ways that were a function of an unforgiving time, but the author of groundbreaking measures to help the poor, extend protections to suspected felons and ease bans on the printing and selling of books" (Burns, 2012: 1/4). He was also, they maintain, a handsome, well-shaped man. As an evidence, the society has erected a statue in a Leicester public park commemorating the king that, per the dig's chronicler Mike Pitts, was "Noble in sight, noble in deed .... without a hint of deformity" (45-47). The source of the rumours about his evil deeds and physical disfigurement was Tudor propaganda, set in 
motion by Henry VII, as soon as he swung the naked corpse of Richard III over a horse and paraded him through Leicester. In this view, Holinshed's, More's, and Shakespeare's accounts (to name the seminal few) were nothing more than deliberate (or accidental, in Shakespeare's case, since we would never dare suggest that the Bard participated in political slander) smears aimed to legitimize the Tudors whose claim to the throne was far weaker than Richard's own. On the other side has been the popular record, both historical and imaginative, that gleefully detailed Richard's reported and imaginary mis-deeds and delighted in shuddering in disgust at the neat package of deformed evil that Richard had come to represent.

For the Richard III society, the dig's findings were, on the one hand, a vindication: the hired ULAS team of highly specialized scientists hypothesized that there was a roughly zero per cent chance that the remains could ever be located and refused to include searching for them in their realistic project objectives (those were mainly to ascertain the architectural dimensions of the Grayfriars complex). The fact that the remains were found nearly exactly where the society's representatives maintained that they would be, and that "Skeleton 1" that was later confirmed to have been Richard III's was found on the very first day of serious digging, gave everyone pause. Finally, the sole fact that a DNA match could be made-overcoming the expected obstacles of the likely dearth of surviving skeletal DNA and the near impossibility of finding surviving relatives, considering that Richard had no direct descendants and the last documented descendant of the family line died in 1803-was no small miracle. On the other hand, the findings were an immense blow. The society's hypothesis that Richard's disfigurement had been a malicious, widely perpetuated rumour was clearly proven false. In fact, many observers noted how relatively accurate contemporary accounts were in describing his height and his shoulder unevenness. According to the chronicling Pitts, for Philippa Langley, the person who had organized commissioning the excavation on behalf of the Richard III society, the result was a "personal ... disaster"; instead of proving that Richard had been smeared, her legacy has become the undeniable evidence that "Richard III was deformed" (131). At least, she reported, the "arms are ok", and not withered as per Shakespeare's account; that's "some good news then" (132). For Langley, as for the Richard III society, embodiment and interiority disentwined with much difficulty if at all; later, when an anthropologist reconstructed Richard's face using the pinnacle of modern technology and an artist supplied the finishing touches such as hair and clothes, Langley opined: "It doesn't look like the face of a tyrant. He's very handsome. It's like you could just talk to him" (180). Clearly, one form of informative embodiment-severe osteopathic scoliosis-had been substituted by another-a seemingly benign (reconstructed) face as the decisive marker for informing our perception of the king's interiority.

The ULAS team that authored the two official scientific reports published to date, it has to be noted, tried really hard not to take sides in the Richardian/Shakespeare contest, to firmly establish their scientific authority, and to stay valiantly clear of the conflation between Richard's interiority and embodiment. Yet, neither succeeded in steering clear of the voyeuristic sensationalism of scrutinizing Richard's deformed body, further fed by the media outlets that scrutinized their every step, and devoted prominent space in each report to rumination on subject of popular interest. And, despite the patronage of the Richard III Society, they seem to vindicate Shakespeare, who surfaces frequently as a touchpoint in the scientific discourse.

The initial official report, which focused on the first stage of skeletal findings, published by the team in Antiquity in 2013, exemplifies the desire to pin down, once and for all, the holistic identity of Richard III (Buckley et al., 2013). While clearly fulfilling the wishes of their patrons in accomplishing the very unlikely feat of finding a grave by all accounts thought to have been lost, the report seems to come down on the side of Shakespeare. In the very second sentence of the introduction, having duly noted that Richard III was likely "England's most familiar medieval king", the report links the historical excavation with Shakespeare and Richard III's "infamous villain[y]" (520). Short of restoring his reputation as "Good King Richard", the report settles for calling him a "highly controversial figure of both history and drama since his death" in 1485 (520). The preliminary analysis of the skeletal remains, included at the very end of the lengthy report, seems to further feed into the popular imagination. After a few perfunctory remarks, the report notes:

The individual is male, with a gracile build, in his late 20 s to late 30s, compatible with Richard's known age at death of 32 . He had severe idiopathic adolescent-onset scoliosis. This may have been progressive and would have put additional strain on the heart and lungs, possibly causing shortness of breath and pain, although not all scoliosis sufferers experience pain from their condition. Unaffected by scoliosis, he would have stood around $5 \mathrm{ft} 8 \mathrm{in}(1.73 \mathrm{~m})$ tall, above average height for a medieval man, though his apparent height might have decreased as he grew older and his disability may have lifted his right shoulder higher than his left. This is consistent with the few contemporary reports of Richard III's physical appearance. (536)

As Allison Hobgood (2014) has helpfully pointed out, this heavily scientific discourse barely disguises the fact that the report's authors, as they "retroactively extrapolate and catalogue the 'condition' of Richard's living body ... that the king was, indeed, disabled. His skeleton provokes examination and diagnosis ... as if one might finally uncover Richard's 'real' nature by scrutinizing the truths of his 'real' body" (24).

The subsequent report on the osteological findings published in Nature on 2 December 2014, further elaborates on the DNA and chemical properties of Richard's skeleton and links his DNA to his living relatives to establish, beyond doubt, his identity. This report, perhaps even more than Buckley's team, had difficulty suppressing the sensationalist dimensions of its research. The introduction plainly banks on the persistent "mystery" the fate of "one of Shakespeare's most notorious villains", "one of the most famous and controversial English kings", disruptor of the "legitimacy of [his brother's] marriage", and presumed though "yet unproven" murderer of his nephews in pursuit of consolidation of his own power (1/15).

In addition to describing the likely colour of Richard's eyes and hair, this report throws an additional wrench into the proceedings, adding a layer of scandal and hint of deviance previously not considered. While establishing a "perfect" and near-perfect match respectively between the DNA of the skeleton and two surviving "female-line" relatives (the likelihood that a match would be found between the skeleton's DNA and any other being conservatively estimated to 1 in 6.7 million), the DNA pattern in the male-descent line strongly suggests a "false paternity" event in "intervening generations" (2/15). The timing of this event, the report makes sure to point out in the discussion section, could have thrown into question the legitimacy of the rule of generations of subsequent rulers:

One can speculate that a false-paternity event (or events) at some point(s) in this genealogy could be of key historical significance, particularly if it occurred in the five generations between John of Gaunt (1340-1399) and Richard III .... A false-paternity between Edward III (1312-1377) and John 
would mean that John's son, Henry IV (1367-1413), and Henry's direct descendants (Henry V and Henry VI) would have had no legitimate claim to the crown. This would also hold true, indirectly, for the entire Tudor dynasty (Henry VII, Henry VIII, Edward VI, Mary I and Elizabeth I) since their claim to the crown also rested, in part, on their descent from John of Gaunt. The claim of the Tudor dynasty would also be brought into question if the false paternity occurred between John of Gaunt and his son, John Beaufort, Earl of Somerset. If the false paternity occurred in either of the three generations between Edward III and Richard, Duke of York, the father of Edward IV and Richard III, then neither of their claims to the crown would have been legitimate. $(6 / 15)$

While this has absolutely nothing to do with Richard III himself, and while many of the scientists in interviews carefully stated that the excavation and skeletal analysis provides zero information about Richard's psychological or behavioural predispositions, this report on the deviant behaviour of some of his distant female cousins casts further shadow onto his DNA. We may have no proof, in other words, that Richard was (or was not) a villain, but we have concrete evidence that those carrying his DNA had missstepped, at least once. This misstep, the report does not fail to note, has dynastic consequences, throwing into question the legitimacy of generations of English rulers King et al (2014).

Though the report does point out that false paternity is not that unusual, and can be proven on average in about 1-3 per cent of the historical record (so, through some complicated math, the scientists propose that there is a 16 per cent chance of at least one occurring in the Plantagenet line), the media erupted in scandalous glee. Already obsessed with Richard's spine, "weirdly curved in a ghastly S" (Greenblatt, 2013: 3/5), this further juicy titbit spread over the internet like wildfire. "Richard III DNA test finds sex scandal undermining Tudor Dynasty's claim to throne", calls out a headline in The Australian on 12 April 2014, pointing out that a king may have been "cuckolded" (Authors not listed, 2014). The usually fairly restrained Smithsonian reported that "Richard III's DNA Analyiss Reveals Cuckoldry in the Family" (Fessenden, 2014). The New Historian misleadingly reports that "Scientists Discover Shocking Facts About Richard III", implicitly suggesting that the "false paternity event" is associated with the king himself (they also report on the likely colour of his hair and eyes, but that's likely not the "shocking" aspect of the report) (Miller, 2014). And even the usually tame NPR reports that "Richard III's DNA indicates family infidelity", somehow suggesting that Richard had betrayed the family's trust in letting such a fact surface (Interview with Kevin Schurer, 2014). On Morning Edition, Kevin Schurer, one of the ULAS team members who worked on the skeleton, carefully explained that this "event" is not a king reproducing with a mistress - something we've come to accept and even expect-but the far more serious case of "a woman being unfaithful within marriage", which raises implications of "inheritance, ... wealth, passing on a power" (1/2).

To date, the discourse of the dig demonstrated both the ongoing desire for certainty in an inevitably ambiguous historical record, with decreasing layers of complexity in concentric circles radiating from scientific reports at the centre to popular lore further out. In the popular media, the false "paternity event", perhaps generations removed from Richard III, became inscribed on the king's disabled body, satisfying a demand for a tidy correspondence between bodily and behavioural deviance. Thus far, the ULAS team confirmed Richard's scoliosis and established his link to his surviving relatives. While it was yet unable to pinpoint with any certainty his personality or psychological make up, attempts at further DNA study are already under way, seeking to restore his "voice" and perhaps other aspects of his identity.
Because I am infinitely fascinated by the ever-wide reaching influence of the Shakespeare cultural capital, I will in closing reflect on the somewhat tangential presence of Shakespeare in the discursive proceedings framing the excavation and its aftermath. As I noted before, the argument over Richard III's embodiment seemed to have devolved into a competition for the right to the articulation of Richard's "true" identity between the Richardians and Shakespeare, who had come to serve as shorthand for the popular historical record. But even those with ostensibly no axe to grind took cues from Shakespeare as a framework for discussing the event. Ather Mirza, the Director of the University News Centre at the University of Leicester, who was in charge of orchestrating the interaction between the ULAS team, the University, and the media, for instance, gleefully reports on his successful management of the media campaign that garnered gigantic attention to the University and the City of Leicester, and which will bring untold but highly anticipated millions to the region (Mirza, 2014). He credits much of the success to the careful staging of the interactions, much like theatre: "we create a sense of theater by having medieval knights"(1), and sought to create ongoing "dramatic" effect by the gradual release of gathered data which "whetted the media's appetite", sometimes going for entire periods without updates deliberately to create "a hush" like "in theatre before the curtain rises"(2). The process of identity-formation during the excavation seems to have been reciprocal, while the dig identified the king and revealed that "there was a lot more to Richard than Shakespeare's 'poisonous hunchbacked toad' " (4), Richard, in turn, "gave the University of Leicester an identity which no money could have bought" (3), all riding on the back of the cultural capital that Shakespeare's intervention seems so graciously to bestow.

The much-cited chronicler Mike Pitts, too, cashes in on Shakespeare's name. His chronicle of the dig is wedded to Shakespeare from the start, where historical material about Richard is illustrated by stills from Shakespeare productions of Richard III, perhaps foreshadowing the conclusion that Shakespeare and history will prove interchangeable. Pitts also helpfully notes that, like Richard III's reported birth in Shakespeare, the finding of his remains was marked by a thunderstorm. And, perhaps imaginatively so, the entire chronicle is structured as a play in five acts, sandwiched between a Prologue and an Epilogue.

On all fronts, it seems, Shakespeare has had an undeniable presence in the excavation discourse. I will end with one last example-our own estimable Stephen Greenblatt, whose "ghastly S" I cited above. Perhaps not surprisingly, Greenblatt's rumination on the "Shape of a Life" of Richard III in The New Yorker suggests that Shakespeare, after all, got it right, once again. Reflecting on the likely correspondence between Richard's interiority and the treatment he received from those around him, which in turn drove him to the ghastly acts he commits in the play, Greenblatt concludes: "the [excavated] skeleton seems to confirm Shakespeare's intuition that there is a relationship between the shape of a spine and the shape of a life" (5/5).

\section{Notes}

1 I've discussed Richard's embodiment from two previous angles: In "Rebellious Shakespeare: the case of transcontinental Richard III" I've explored the way in which the neoliberal cultural context tends to produce similar Richards in Shakespearean productions that are geographically remote: one in the postcommunist Czech Republic, the other in a post apartheid South Africa. "Richard Recast: Renaissance disability in a postcommunist culture", in turn, explores the ways in which productions of Shakespeare's Richard III can mirror an existential anxiety on part of a populations' majority produces heightened negative discriminatory discourse aimed at suddenly "undeserving" minorities (Kostihova, 2013, 2014).

2 The great majority of media reports begins with a gleeful description of the now proven disfigurement, usually presented within the same sentence with a citation of 
Shakespeare's depiction of Richard III as a murderous tyrant. Popular Mechanics reports in the first paragraph: "Two years ago, a battle-worn, scoliosis-riddled skeleton was unearthed beneath a parking lot in Leicester, England. Based on the evidence at hand, the archeologists behind the discovery claimed that they had found the bones of Richard III-the 15th century monarch with the cartoonishly villainous reputation. (Richard, immortalized in one of Shakespeare's greatest plays, reportedly stole the throne, killed his nephews, and ruled for two years before dying in battle)" (Herkewitz, 2014). This report, too, notes that "Adultery Muddles Science Yet Again". The LA Times report's first paragraph: "Is now the summer of his disinterment? Archaeologists digging in central England for the remains of Richard III, the king immortalized as a murderous tyrant by William Shakespeare, have found bones that in many ways match his profile-literally" (Chu, 2012). The Times report early on (since this is endnotes, I won't spare the reader the sordid details): "'God and your arms be prais'd, victorious friends; The day is ours, the bloody dog is dead,' says Henry-Earl of Richmond, soon to be Henry VII-in the final scene of Shakespeare's Richard III". "Yes, yes, but where is 'the bloody dog' buried? Beneath the tarmac of a municipal car park in Leicester, possibly. Pending laboratory analysis". "I shall despair", Richard complained as death readied to ambush him at the Battle of Bosworth in 1485. "There is no creature loves me; And if I die, no soul shall pity me". Pity you? Maybe not, but that hasn't stopped them looking for you. "Archeologists at the University of Leicester digging at the site ... have found a skeleton of an adult male with a metal arrowhead in its back. More tantalizingly, they say that the well-preserved remains show signs of scoliosis" ("King's Evidence"; the article has no author, but it is indexed under the subjects of Archaeology, Scoliosis and Spine, respectively; Authors not listed, 2012).

\section{References}

Buckley R, Morris M, Appleby J, King T, O’Sullivan D and Foxhall L (2013) “The king in the car park" new light on the death and burial of Richard III in the Grey Friars church, Leicester, in 1485. Antiquity; 87 (336), 519-38.

Burns JF (2012) Discovery of skeleton puts Richard III in Battle once again. The New York Times 23 September.

Chu H (2012) Bones found may be English king. Los Angeles Times 4 September 13.

Fessenden M (2014) Richard III's DNA analysis reveals Cuckoldry in the family. Smithsonian.com, 2 December.

Greenblatt S (2013) The shape of a life. The New Yorker 5 February.

Herkewitz W (2014) Scientists confirm these really are the bones of Richard III. Popular Mechanics 2 December.

Hobgood AP (2014) Teeth before eyes: Impairment and invisibility in Shakespeare's Richard III. In: Iyengar S (ed). Disability, Health and Happiness in the Shakespearean Body. Routledge: New York and London, pp 23-40.

King TE et al (2014) Identification of the remains of King Richard III. Nature Communications 2 December, <http://www.nature.com/ncomms/2014/ 141202/ncomms6631/full/ncomms6631.html>, accessed 15 January 2015.

(2012) King's Evidence: Have archaeologists in Leicester found the battle scarred remains of Richard III? The Times 13 September 2.
Kostihova M (2013) Richard recast: Renaissance disability in a postcommunist culture. In: Hobgood A and Wood D (eds). Recovering Disability in Early Modern England. Ohio University Press: Columbus, OH, pp 136-149.

Kostihova M (2014) Rebellious Shakespeare: The case of transcontinental Richard III. Global Shakespeare Journal; 1 (1): 54-67.

Mantel H (2013) Royal bodies. London Review of Books, V35 N4, 21 February: 3-7. Online, http://www.lrb.co.uk/v35/n04/hilary-mantel/royal-bodies, accessed 28 January 2015.

Miller L (2014) Scientists discover shocking facts about Richard III. New Historian 6 December.

Miller W (1997) The Anatomy of Disgust. Harvard University Press: Cambridge.

Mirza A (2014) The king under the car park. Perspectives: Policy and Practice in Higher Education. Taylor and Francis, pp 1-5.

Pitts M (2014) Digging for Richard III: The Search for the Lost King. Thames and Hudson: London.

Interview with Kevin Schurer (2014) Richard III DNA indicates family infidelity. Interview between Steve Inskeep and Kevin Schurer. NPR: morning edition. 5 December.

(2014) Richard III DNA test finds sex scandal undermining Tudor dynasty's claim to the throne. The Australian. 3 December.

(2015) Richard III Society website, http://www.richardiii.net/, accessed 15 January 2015

Snyder S (2005) Unfixing disability. In: Sandahl C and Auslander P (eds). Bodies in Comotion: Disability and Performance. University of Michigan Press: Ann Arbor, MI.

\section{Additional information}

Competing interests: The authors declare no competing financial interests.

Reprints and permission information is available at http://www.palgrave-journals.com/ pal/authors/rights_and_permissions.html

How to cite this article: Kostihova M (2016) Digging for perfection: discourse of deformity in Richard III's excavation. Palgrave Communications. 2:16046 doi: 10.1057/ palcomms.2016.46.

(c) (i) This work is licensed under a Creative Commons Attribution 4.0 cc International License. The images or other third party material in this article are included in the article's Creative Commons license, unless indicated otherwise in the credit line; if the material is not included under the Creative Commons license, users will need to obtain permission from the license holder to reproduce the material. To view a copy of this license, visit http://creativecommons.org/licenses/by/4.0/ 